\title{
Seasonality of Cross-sectional Return Volatility in the Jordan Stock Market
}

\author{
Malik R. Elhaj", Shah Saeed H. Chowdhury \\ Accounting \& Finance Department, Prince Mohammad Bin Fahd University (PMU), Kingdom of Saudi Arabia
}

Copyright $\mathrm{C} 2016$ by authors, all rights reserved. Authors agree that this article remains permanently open access under the terms of the Creative Commons Attribution License 4.0 International License

\begin{abstract}
One important gap in finance literature is the seasonality in volatility. Just like the seasonality in stock returns it is possible that volatility may also have a pattern. Time series volatility is related to previous values and it is sticky in nature. Thus, detection of seasonality in volatility may be difficult. Therefore, we use cross-sectional volatility from daily returns of a cross-section of firms (in our case, sectors) and examine the relationship between daily cross-sectional volatility and day of the week, turn of the month and turn of the year. This paper examines how the cross-sectional volatility of the Jordanian stock market may change due to the day of the week, turn of the month and turn of the year. Results show strong evidence of reduction of volatility on Thursday compared to Sunday, and significantly lower volatility on the first three days of the month compared to the third day before the last day of the month. Thus, this finding is important for investors to better understand risk.
\end{abstract}

Keywords Cross-sectional Volatility, Amman Stock Market, Capital Market, Seasonality of Volatility, Emerging Markets.

\section{Introduction}

Capital market efficiency has been a popular topic for empirical research since Fama [15], [16] described the theoretical analysis of market efficiency (Efficient Market Hypothesis). Subsequent to the Fama studies a great deal of research was devoted to investigating the randomness of stock price movements for the purpose of measuring the efficiency of capital markets around the world. More recently, researchers have been more focused on market inefficiency by detecting various forms of systematic variations (or regularities) in stock returns.

Any predictable pattern in asset returns may be exploitable and therefore is considered as evidence against the weak form of market efficiency. Although there was initially enough evidence in support of the semi-strong form of efficiency in the developed stock markets, researchers have found some genuine anomalies in stock returns even in these markets. Most common anomalies are (1) size premium, (2) seasonal anomalies, (3) value versus glamour, and (4) overreaction/underreaction hypothesis. ${ }^{1}$ Four statistically significant seasonal patterns found in the U.S. and the other developed countries' stock market returns are the weekend effect, turn-of-the-month effect, turn-of-the-year effect, and holiday effect. These return regularities may provide opportunities for to the investors/traders to make significant profit around these periods by taking appropriate trading strategies.

Unlike seasonality in returns, we are not looking at the magnitude of volatility. We would rather look at whether volatility on a given day is different from that on the reference day. Even if the pattern cannot be employed directly in a trading rule because of transaction costs, it may enable people to change trade timing and frequency. For example, an investor who is going to trade anyway may avoid trading activities on a day of high historical volatility. Thus, a risk-averse trader who is going to transact anyway can benefit by altering his timing to buy and sell when volatility is expected to be less. A similar study by Camilleri [10] finds that the January effect is present in the Malta Stock Exchange and volatility increases toward the end of the month. A similar phenomenon may exist in the Jordanian stock market. This paper studies the seasonality of cross-sectional volatility measured from the Amman Stock Exchange (ASE) stock returns. This is the first paper that examines the seasonality of cross-sectional volatility of any stock market in the Middle East and North Africa (MENA)

1 In many studies it has been found that the stocks with small market capitalizations (small stocks) have outperformed stocks with large market capitalizations. A number of papers have argued that stocks with high book value to stock price ratios and/or high earnings to price ratios (generally called value stocks) outperformed stocks with low ratios (glamour stocks) in the past.

Two studies by DeBondt and Thaler $(1985 ; 1987)$ show that stocks experiencing a poor performance over 3-5 year period subsequently outperform stocks that had previously performed relatively well. This implies that, on average, stocks which are 'losers in terms of their returns subsequently become 'winners' and vice versa This kind of market inefficiency/regularity is referred to as 'overreaction hypothesis'. 
region.

This paper is organized as follows. Section 2 provides some information for the ASE and Jordanian economy. Section 3 gives a brief review of previous literature on the seasonality of stock returns and the volatility of the ASE. Section 4 explains the data and methodology used. Section 5 provides the results of the econometric models used in the study. Section 6 concludes the paper.

\section{An Overview of Amman Stock Exchange}

The Amman Stock Exchange (ASE) was established in March 1999 as a non-profit institution with administrative and financial autonomy. It is authorized to function as an exchange for the trading of securities. The exchange is governed by a seven-member board of directors. A Chief executive officer oversees the ASE's day-to-day responsibilities and reports to the board. The ASE membership is comprised of 58 Jordanian brokerage firms.

The ASE is committed to the principles of fairness, transparency, efficiency, and liquidity. The Exchange seeks to provide a strong and secure environment for its listed securities while protecting and guaranteeing the rights of its investors. To provide this transparent and efficient market, the ASE has implemented internationally recognized directives regarding market divisions and listing criteria. To comply with international standards and best practices, the ASE works closely with the Jordan Securities Commission (JSC) on surveillance matters and maintains strong relationships with other exchanges, associations, and international organizations. The exchange is an active member of the Arab Federation of Exchanges, the Federation of Euro-Asian Stock Exchanges (FEAS), and is a full member of the World Federation of Exchanges (WFE).

The most important functions of the ASE include: (i) providing enterprises with a means of raising capital by listing on the Exchange, (ii) encouraging an active market in listed securities based on the effective determination of prices and fair and transparent trading by providing modern and effective facilities, (iii) monitoring and regulating market trading, (iv) setting out and enforcing a professional code of ethics among its member directors and staff, and (v) ensuring the provision of timely dissemination of accurate information to the market.

The recent performance of the ASE has been exceptional, partly reflecting long-standing domestic efforts to promote financial equity markets. The average annual increase of the ASE index since 2000 has been 36 percent compared with the historical average of 13 percent. Since the establishment of the Jordanian capital market in 1978, its legal foundations have been strengthened and hence its products and liquidity improved. The ASE has matured through a gradual process. It has diversified the types of financial instruments available to investors and has removed most restrictions on foreign participation in listed companies [33].
Table 1 summarizes the achievements of the ASE during the period 2005-2014. The best time for the market was perhaps the period 2005-2008. After that, the market has been on a slide in terms of many indicators. The ASE index reached its highest point in 2005, and since 2008 it has been gradually going downward. The biggest market in the region, the Saudi stock market crashed in 2005also. This along with the global financial crisis of 2008 and the political unrest in the Arab world since the Arab Spring could be the reasons for this stock market slide. From the investors' point of view it may be the best time to invest in this market as the dividend yield increased from $1.60 \%$ in 2005 to $4.18 \%$ in 2014 . Even after the low stock price in 2014, the market depth (market capitalization/GDP) is still about $80 \%$, indicating the significant importance of the stock market in the Jordanian economy.

\section{Literature Review}

In this section, we discuss some of the important papers that shed light on the Jordanian stock market in general and seasonality in particular. Based on the data from 02/1979 through 06/1992, Harvey [18] reports annualized standard deviation of $17.41 \%$ and autocorrelation of 0.08 , suggesting a predictable behavior of this market to some extent. Interestingly, the observed volatility of Jordan is reasonably less than that of many other emerging markets. Mawla [22] provides evidence for selected Arab stock markets that there is no significant effect of stock market liquidity on the economic growth. Abdul-Khalig [1] reports that for the ASE there is no significant relationship between the market capitalizations to GDP ratio and the economic growth, but the turnover has significant effect on growth. The possible justification for this result is that the ASE performance is more relies than other Arab countries in terms of external financial flows such as workers' remittances, Arab aid, and foreign investment. Kabajeh et al. [18] investigate the relationship between the ROA (Return on Asset), ROE (Return on Equity) and ROI (Return on Investment) and Jordanian insurance stock prices during 2002- 2007 and report a positive relationship.

Abu Shanab [3] finds no effect of risk in the share price for 38 companies listed on the ASE for the period 2000-2007. Another study by Al Kurdi [7] shows the significant power of published accounting information to predict the share prices of 110 Jordanian companies for the period 1995-2004. This result is also supported by Al Qudah [8]. Abu Hasheesh [2] finds a positive effect of net profit to equity ratio, net profit to total assets ratio, and dividends to net profit ratio on the stock prices of 40 Jordanian firms. The results also show a negative effect of fixed assets to total assets ratio, total creditors to cash sources, and wages to total expenses ratio on stock prices. Khrawish et al. [19] report positive effect of interest rate changes on the stock market capitalization of the ASE over the period 1999-2008. 
Table1. Key Statistics of Amman Stock Exchange, 2005-2014

\begin{tabular}{ccccccccccc}
\hline Relevant Features & $\mathbf{2 0 0 5}$ & $\mathbf{2 0 0 6}$ & $\mathbf{2 0 0 7}$ & $\mathbf{2 0 0 8}$ & $\mathbf{2 0 0 9}$ & $\mathbf{2 0 1 0}$ & $\mathbf{2 0 1 1}$ & $\mathbf{2 0 1 2}$ & $\mathbf{2 0 1 3}$ & $\mathbf{2 0 1 4}$ \\
\hline Number of Listed Companies & 201 & 227 & 245 & 262 & 272 & 277 & 247 & 243 & 240 & 236 \\
\hline $\begin{array}{c}\text { Market Capitalization } \\
\text { (Billion) }\end{array}$ & 26.66 & 21.08 & 29.21 & 25.41 & 22.53 & 21.86 & 19.23 & 19.14 & 18.23 & 18.08 \\
\hline $\begin{array}{c}\text { Value Traded (Billion) } \\
\text { Average Daily Trading } \\
\text { (million) }\end{array}$ & 16.87 & 14.21 & 12.35 & 20.32 & 9.66 & 6.69 & 2.85 & 1.98 & 3.03 & 2.26 \\
\hline $\begin{array}{c}\text { No. of Shares Traded } \\
\text { (million) }\end{array}$ & 2,583 & 4,104 & 4,479 & 5,442 & 6,022 & 6989 & 4072 & 2,384 & 2,706 & 2,322 \\
\hline $\begin{array}{c}\text { No. of Transactions } \\
\text { (Thousand) }\end{array}$ & 2,392 & 3,443 & 3,458 & 3,781 & 2,965 & 1880 & 1318 & 975 & 1074 & 956 \\
\hline No. of Trading Days & 244 & 242 & 247 & 245 & 249 & 250 & 247 & 251 & 245 & 249 \\
\hline Turnover Ratio (\%) & 94.11 & 101.1 & 91.2 & 91.50 & 91.30 & 102.20 & 58.20 & 33.90 & 38.00 & 32.81 \\
\hline ASE General Index & 8191 & 5518 & 7519 & 6243 & 5520 & 5318 & 4648 & 4594 & 4337 & 2165 \\
\hline ASE General Free Float Index & 4260 & 3014 & 3675 & 2758 & 2533 & 2374 & 1995 & 1958 & 2066 & 4238 \\
\hline $\begin{array}{c}\text { P/E Ratio (times) } \\
\text { Dividend Yield }\end{array}$ & 44.20 & 16.70 & 28.00 & 18.80 & 14.40 & 26.30 & 22.60 & 15.60 & 14.74 & 15.31 \\
\hline $\begin{array}{c}\text { (\%) } \\
\text { Non-Jordanian Ownership }\end{array}$ & 45.00 & 45.50 & 48.90 & 49.20 & 48.90 & 49.60 & 51.30 & 51.70 & 49.89 & 48.80 \\
\hline $\begin{array}{c}\text { Market Capitalization / GDP } \\
\text { (\%) }\end{array}$ & 326.6 & 233.9 & 289.0 & 216.7 & 149.6 & 122.7 & 102.7 & 93.5 & 83.01 & 75.75 \\
\hline Jordan GDP (Billion) & 17.78 & 21.27 & 24.16 & 31.03 & 33.64 & 37.33 & 40.73 & 43.70 & 47.46 & 50.61 \\
\hline
\end{tabular}

$\mathrm{Al}$ Amarneh et al. [4] study the ASE listed companies for the period 2005-2009 in order to explore the institutional preferences for large capitalization stocks. Their results show a positive relationship between institutional investment and financial performance. Rubin et al. [27] find the correlation between volatility and institutional ownership based on the firm's dividends policy particularly around the dividend declaration days. Rakotomaves [25] provide evidence that institutions prefer stocks that have low effective spread, large average trade size, and low trading frequency, low volatility, and low price impact. Gompers and Metrick [16] find that in comparison with institutional investors, individual investors prefer stocks of larger market capitalization and more liquid companies. However, they do not detect any significant relation between institutional holdings and stock return volatility. In the last two decades, the ASE has had an amazing advancement as far as exchanging volume and market esteem are concerned, and has turned itself into an important channel by which to invest in Jordan. Maghayreh [20] shows that the ASE differs from other regional markets in terms of price movements, business sector manipulations, and government involvements. He finds a co-integrated relationship in the long term between the stock index and foreign reserve, interest rates, inflation, exports, and industrial production. $\mathrm{He}$ also finds that the ASE is more sensitive to economic and political changes compared to other neighboring Arab countries.

There are few papers related to seasonality in the Jordanian stock market. All of these papers focus on the seasonality of stock returns - and seasonality of volatility of returns has remained ignored altogether. Some of the papers on seasonality in stock returns are discussed here. Maghayreh [21] finds a significantly higher return in January compared to other months of the year. Rozeff and Kinney [31], and Nassir and Mohammad [23] have found similar January effects in the U.S. and Malaysia markets, respectively. Al-Rjoub [9] uses the data for the period 1992-2002 and reports a significantly positive return on Thursday and a negative return on Monday (the second day of the week). Al-Jarrah et al. [5] show that the realized rates of return from trading at the beginning of the month are not statistically higher than the rates of return realized from trading during the remaining days of the month. The findings of Alrabadi and Al-Qudah [6] indicate that returns are significantly higher on Sundays (the first day of trading of the week) and Thursdays (the last trading day of the week) than on other days of the week. Moreover, a highly significant January effect exists. Finally, their results suggest that most returns occur on the turn of the month rather than during the remaining days of the month.

Maghayreh [20] utilized three distinctive but related Autoregressive Conditional Heteroskedasticity models: the standard GARCH, the exponential GARCH (EGARCH) and the GJR models. The GARCH class of models used in this study has proven to be particularly suited for modeling the behavior of financial data. The results demonstrate no proof of month to month regularity in stock returns. In addition, he finds no confirmation for the January impact. These outcomes show that financial specialists cannot exploit data about the month of the year to make abnormal profits.

Al-Rjoub [9] investigates the robustness of evidence on weekend anomaly in stock return data after accounting for the possible errors and sample sizes. Their results show a 
negative or low average return on the weekend when Wednesday is the last day of the week, whereas the average return is positive or high when Thursday becomes the last day of the week. The possible explanation for the high return on the weekend is related to the settlement practices which imply unusually high closing on Thursdays and consequently lower closer on Mondays. Another reason could be the fact that negative news is usually released over the weekend.

Another study published by Sedik and Petri [28] reports a substantial increase in price volatility in the ASE as measured by the monthly standard deviation of daily returns. The increase in volatility has been particularly pronounced after March 2005. Empirically, price volatility tends to increase substantially in the period immediately before the bursting of a price bubble, and financial observers often use it as an important warning signal.

Polak and Ejaz [24] conduct research to find the short-term momentum effect in stock markets of the Middle East and to examine whether short-term momentum profits can be explained by the risk-based CAPM model. The sample of their study consists of six major stock markets (Jordan, Egypt, Morocco, Saudi Arabia, Abu Dhabi, and Dubai). The evidence from these markets shows a significant short-term profit momentum effect. This finding is aligned with the finding in other developed countries, which suggests that these Middle East markets are not isolated. But this study does not include enough stock markets from the Middle East to have a better understanding of the short-term momentum effect, and also fails to explain any differences among the sampled countries.

Sedik and Petri [28] analyze the recent developments in the ASE and its linkages to other Arab countries. Their study provides evidence that the ASE is integrated with other Arab markets but not with other emerging and developed stock markets. The reasons as stated by the authors include stock markets investment barriers, cultural issues, and deregulation and privatization policies. They suggest that Jordan should continue enhancing the transparency and effectiveness of regulation and supervision of its capital markets so as to distinguish itself further from other markets. This would be important, as Jordan will likely rely on foreign capital inflows in the foreseeable future. Moreover, it would tend to reduce any potential contagion from adverse regional developments.

\section{Data and Methodology}

\subsection{Data}

To be in line with the previous similar research, market returns have been calculated from the log difference in the index of two consecutive trading days. ${ }^{2}$ Daily 23 ASE

2 Daily return of a stock $=$ Natural $\log$ of (Today's price/Previous day's price) x 100 . industry index data from July 2006 through February 2015 has been used for the purpose of the study. Daily closing index data are collected from the ASE website. We need to find the daily cross-sectional volatility of returns. We use the following formula to find the daily cross-sectional volatility of returns of the market.

$$
\text { vol }_{m, t}=\sqrt{\frac{\sum_{i=1}^{n}\left(r_{i, t}-\overline{r_{t}}\right)^{2}}{n-1}}
$$

Where $v l_{m, t}$ and $r_{i, t}$ are cross-sectional market volatility and individual stock returns on day $t$, respectively.

We use this simple volatility measure for certain reasons. We could have used more advanced volatility measures such as GARCH models. Time series models like GARCH provides conditional volatility based on the coefficients derived from the whole sample period. For our research, if we use such a measure of volatility, it will become dependent upon the future and thus a study on seasonality is useless. On the other hand, we use the cross-sectional volatility which is not dependent upon the future and can be linked to particular days.

\subsection{Cross-sectional Volatility and the Day-of-the-Week Effect}

To find the difference of cross-sectional volatility between Sunday and other days of the week, we use the following regression equation

$$
\text { vol }_{t}=\alpha_{0}+\alpha_{1} D_{1 t}+\alpha_{2} D_{2 t}+\alpha_{3} D_{3 t}+\alpha_{4} D_{4 t}+\varepsilon_{t}
$$

where $t=1,2,3, \ldots, T$ and $v l_{t}$ is the cross-sectional volatility of the ASE on day $t$ and $D_{1 t}, D_{2 t}, D_{3 t}$, and $D_{4 t}$ are dummy variables that equal 1 if trading day $t$ is Monday, Tuesday, Wednesday and Thursday (closing day), respectively, and 0 otherwise. Thus the constant term captures the effect of Sunday and other coefficients provide us the difference of average volatility between Sunday and other days of the week.

\subsection{Cross-sectional Volatility and the Turn-of-the-Month Effect}

The daily cross-sectional volatility for six days around the turn of the month is considered to trace the volatility characteristics around the turn of the month. The regression model is given below.

$$
\text { vol }_{t}=\alpha_{0}+\alpha_{1} D_{1 t}+\alpha_{2} D_{2 t}+\alpha_{3} D_{3 t}+\alpha_{4} D_{4 t}+\alpha_{5} D_{5 t}+
$$

Where $t=1,2,3, \ldots, T$ and $D_{1 t}, D_{2 t}, D_{3 t}, D_{4 t}$, and $D_{5 t}$ are dummy variables that equal 1 if trading day $t$ is the second last day of the month, last day of the month, first day of the next month, second day of the next month and third day of the next month, respectively, and 0 otherwise. Hence the constant term captures the effect of the third last day of the present month and other coefficients provide us with the difference of average volatility between the third last day of the present month and other days. 


\subsection{The Turn-of-the-Year Effect}

We also examine if volatility is related to the last and first few days of a year. Using the following model, seasonality of volatility of returns is checked for the last three days of December and the first three days of January.

$$
\text { vol }_{t}=\alpha_{0}+\alpha_{1} D_{1 t}+\alpha_{2} D_{2 t}+\alpha_{3} D_{3 t}+\alpha_{4} D_{4 t}+\alpha_{5} D_{5 t}+
$$

where $t=1,2,3, \ldots, T$ and $D_{1 t}, D_{2 t}, D_{3 t}, D_{4 t}$ and $D_{5 t}$ are dummy variables that equal 1 if trading day $t$ is the second last day of December, last day of December and first day of January, second day of January, and third day of January, respectively, and 0 otherwise. Hence the constant term captures the effect of the third last day of the December and other coefficients provide us with the difference of average volatility between the third last day of December and other days.

\section{Analyses of Results}

Figure 1 exhibits the daily cross-sectional volatility of the ASE. Usually the volatility is less than two percent throughout the study period. From time to time there is a tendency for volatility to cross the two percent mark, indicating some sort of presence of pattern or predictability of volatility. There is one very large spike of volatility in October 2013 to the extent of more than six percent.

Table 2 provides the summary statistics of daily returns and daily cross-sectional returns volatility for the periods 07/2006-02/2015, 07/2006-12/2010 and 01/2011-02/2015. Mean returns in all periods are similar although mean standard deviation in $01 / 2011-02 / 2015$ is lower than that in the previous period. Also, the standard deviation of returns in the later period is much smaller than that in the previous period.
Table 3 exhibits the day-of-the-week effect of volatility. Panel A gives the results of the basic regression model consisting of five days of the week. To avoid the so-called dummy variable trap, we use the intercept term as a proxy for Sunday, the first day of the week. In this framework coefficient of intercept (Sunday) provides the mean volatility on Sundays, whereas other coefficients tell us the difference from mean volatility on Sunday. For the overall period, Thursday, the last day of the week indicates somewhat seasonality by showing a significant difference in mean volatility between the last and first day of the week. Moreover, Sunday seems to be the most volatile day as compared with other days of the week. During the period $01 / 2011-02 / 2015$ we do not observe any seasonality of volatility, whereas during 07/2006-02/2015 we observe a strong presence of seasonality in volatility. In this case, volatility on Thursday is much lower than that on Sunday. Thus, it seems that traders are more enthusiastic at the start of the week, causing a higher level of volatility and as hence a trader may find it safe to avoid trading on the first day of the week. Panel B gives results of regression models that add own lagged return. Results do not change that much. It suggests that past returns do not explain the present cross-sectional volatility of the market.

Figure 2 corroborates the results found in Table 3. It plots the standard deviation of returns of only Sundays and Thursdays. It shows that cross-sectional volatility on Sundays is larger than that on Thursdays - especially during the first period. Results in Table 3, thus, suggest that the market has become more efficient during the past four years. However, almost during the same time market has become less active (as shown in Table 1). It may be possible that less enthusiasm among the investors is the main force behind less divergence of belief and hence less seasonality of volatility of stock returns.

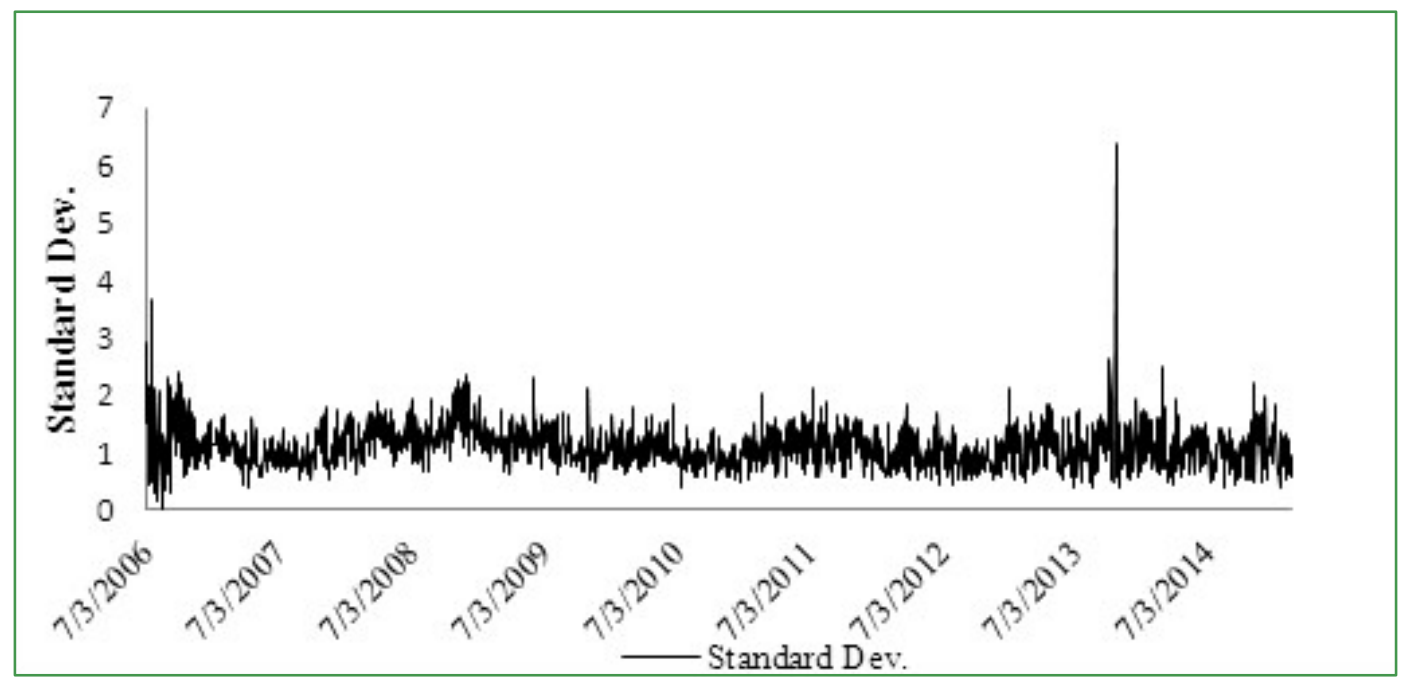

Figure 1. Daily Cross-sectional Standard Deviation of the ASE, 01/2006-02/2015 
Table 2. Summary Statistics for the ASE, 07/2006-02/2015

\begin{tabular}{|c|c|c|c|c|c|c|c|}
\hline Variables & $\mathrm{N}$ & St. Dev. & Min. & Max. & Mean & Med. & Range \\
\hline \multicolumn{8}{|c|}{ Panel A: Whole Period } \\
\hline Standard Deviation & 2135 & 0.36 & 0.02 & 6.38 & 1.08 & 1.06 & 6.36 \\
\hline Returns & 2135 & 0.64 & -3.52 & 4.03 & -0.02 & -0.01 & 7.56 \\
\hline \multicolumn{8}{|c|}{ Panel B: Period, 07/2006-12/2010 } \\
\hline Standard Deviation & 1112 & 0.35 & 0.02 & 3.66 & 1.12 & 1.08 & 3.64 \\
\hline Returns & 1112 & 0.79 & -3.53 & 4.03 & -0.02 & 0.00 & 7.56 \\
\hline \multicolumn{8}{|c|}{ Panel C: Period, 01/2011-02/2015 } \\
\hline Standard Deviation & 1023 & 0.36 & 0.37 & 6.38 & 1.05 & 1.02 & 6.01 \\
\hline Returns & 1023 & 0.44 & -2.33 & 1.44 & -0.02 & -0.01 & 3.77 \\
\hline
\end{tabular}

Table 3. Regression Results for Day-of-the-week Effect of Volatility

\begin{tabular}{|c|c|c|c|c|c|c|}
\hline \multirow[b]{2}{*}{ Variable } & \multicolumn{2}{|c|}{ 07/2006-02/2015 } & \multicolumn{2}{|c|}{ 07/2006-12/2010 } & \multicolumn{2}{|c|}{ 01/2011-02/2015 } \\
\hline & Estimates & $t$-value & Estimates & $t$-value & Estimates & $t$-value \\
\hline \multicolumn{7}{|c|}{ Panel A: regression results for five days } \\
\hline Intercept & 1.10 & $64.08^{* * *}$ & 1.16 & $50.26^{* * *}$ & 1.04 & $40.86^{* * *}$ \\
\hline Monday & 0.00 & -0.10 & -0.03 & -0.78 & 0.02 & 0.68 \\
\hline Tuesday & -0.02 & -0.76 & -0.02 & -0.64 & -0.01 & -0.39 \\
\hline Wednesday & -0.02 & -1.00 & -0.06 & $-1.77^{*}$ & 0.01 & 0.35 \\
\hline Thursday & -0.04 & $-1.84^{*}$ & -0.09 & $-2.59^{* *}$ & 0.00 & 0.00 \\
\hline \multicolumn{7}{|c|}{ Panel B: regression results for five days with lagged returns } \\
\hline Intercept & 1.11 & $64.42^{* * *}$ & 1.16 & $50.87^{* * *}$ & 1.04 & $40.46^{* * *}$ \\
\hline Monday & -0.01 & -0.29 & -0.03 & -1.01 & 0.03 & 0.74 \\
\hline Tuesday & -0.02 & -0.84 & -0.02 & -0.74 & -0.01 & -0.3 \\
\hline Wednesday & -0.02 & -1.06 & -0.06 & $-1.84^{*}$ & 0.01 & 0.42 \\
\hline Thursday & -0.05 & $-1.89^{*}$ & -0.09 & $-2.68^{* *}$ & 0.00 & 0.06 \\
\hline Lagged return & -0.01 & -0.88 & -0.02 & -1.16 & 0.01 & 0.35 \\
\hline
\end{tabular}

${ }^{*}, * *$, and ${ }^{* * *}$ indicate significance at $10 \%, 5 \%$, and $1 \%$, respectively.

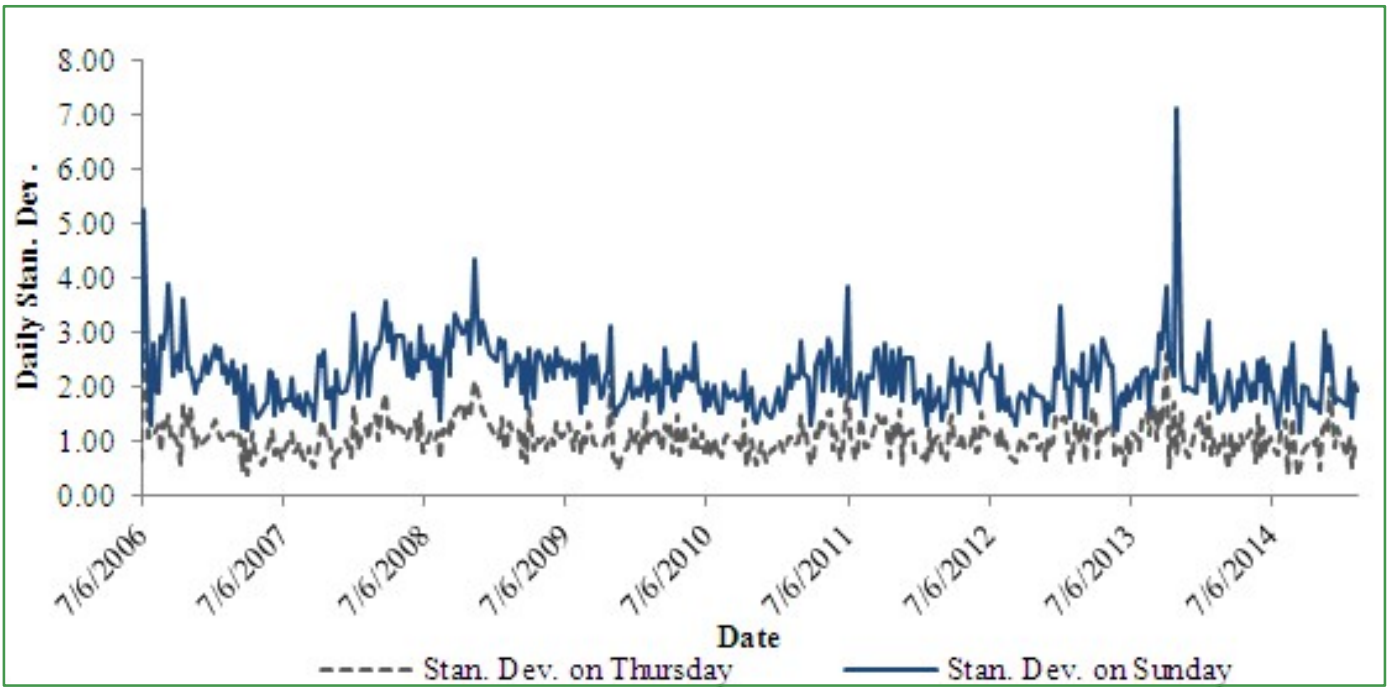

Figure 2. Cross-sectional Stan. Dev. on Thursday and Sunday 
Table 4. Regression Results for Turn-of-the-month Effect of Volatility

\begin{tabular}{ccccccc}
\hline & \multicolumn{2}{c}{$07 / 2006-02 / 2015$} & \multicolumn{2}{c}{$01 / 2011-02 / 2015$} & \multicolumn{2}{c}{$07 / 2006-12 / 2010$} \\
\hline Variable & Estimates & $t$-value & Estimates & $t$-value & Estimates & $t$-value \\
\hline Intercept & 1.21 & $35.91^{* * *}$ & 1.16 & $24.28^{* * *}$ & 1.27 & $26.64^{* * *}$ \\
Day (-2) & -0.06 & -1.35 & -0.08 & -1.23 & -0.05 & -0.70 \\
Day (-1) & -0.04 & -0.75 & 0.01 & 0.19 & -0.08 & -1.21 \\
Day 1 & -0.11 & $-2.33^{* *}$ & -0.11 & -1.64 & -0.11 & $-1.69^{*}$ \\
Day 2 & -0.11 & $-2.29^{* *}$ & -0.07 & -1.01 & -0.15 & $-2.23^{* *}$ \\
Day 3 & -0.10 & $-2.10^{* *}$ & -0.02 & -0.36 & -0.17 & $-2.56^{* *}$ \\
\hline
\end{tabular}

${ }^{* * *}$, and ${ }^{* * *}$ indicate significance at $10 \%, 5 \%$, and $1 \%$, respectively.

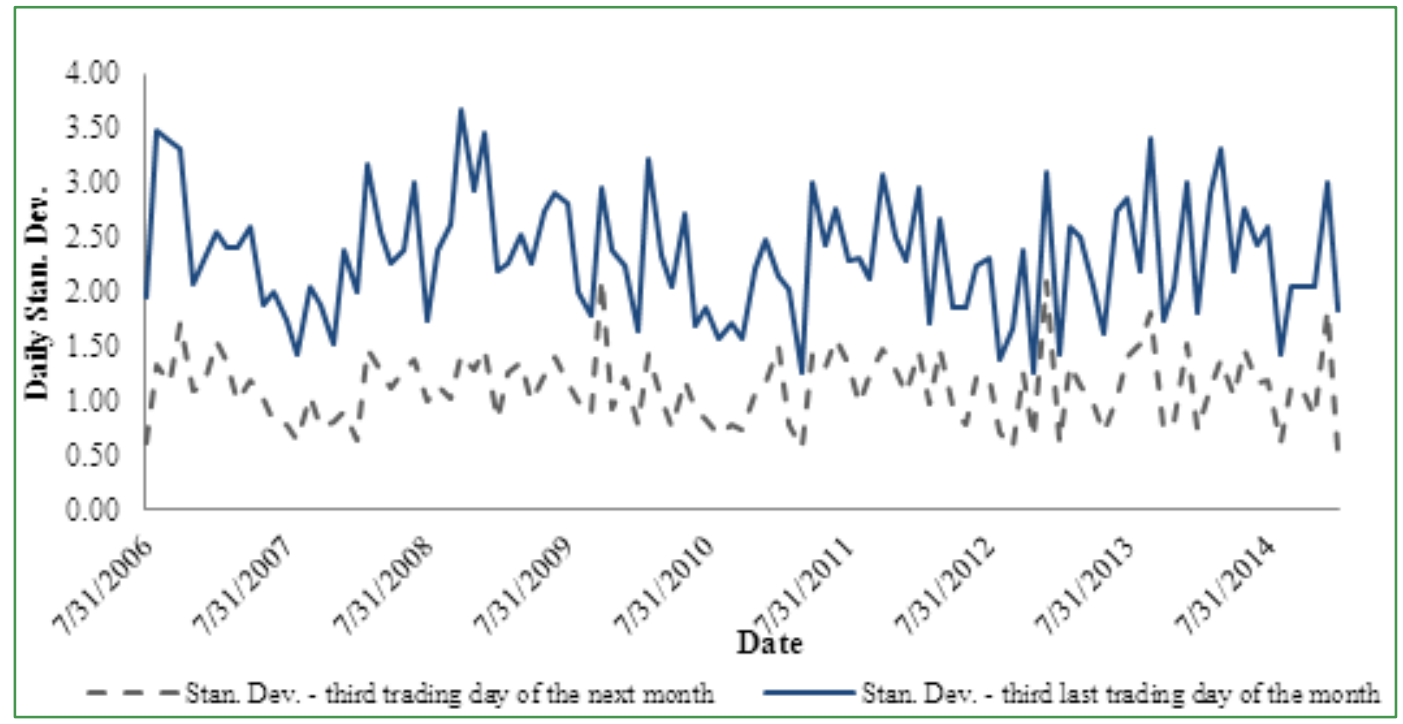

Figure 3. Cross-sectional Stan. Dev. on the Last Third Day of the Current Month and the Third Day of the Next Month

Table 4 shows the seasonality of volatility during the turn of the month. We use the last and the first three trading days of every month to detect this kind of monthly seasonality. For the whole period, cross-sectional volatility on the first three days of the month is significantly lower than that on the third last day of the month. The period 07/2006-12/2010 shows a very strong presence of turn-of-the-month effect. Probably, this strong presence of seasonality is the main reason for the turn-of-the-month effect of the whole period. This finding should have an impact on trade timing. Since volatility is less on the first three days, a risk-averse trader should trade on the first three days of the month. However, the absence of the turn-of-the-month effect during the later period is not surprising since similar results have also been found in Table 3. Figure 3 confirms the results found in Table 4. It plots the standard deviation of only two days - the third last day of previous month and the third day of the current month. It shows that cross-sectional volatility on the third last day of the previous month is larger than that on the third day of the current month - especially during the first period.

Table 5 shows the cross-sectional volatility around the last three days of the previous year and the first three days of the next year. We do not find a strong turn-of-the-year effect in the Jordanian stock market. Only the second day of the New Year shows the presence of this effect at $10 \%$ level of significance. Thus, investors do not behave that much differently during the turn of the year. For trading purposes, investors may be indifferent between the last and the first days of the year.

Table 5. Regression Results for Turn-of-the-year Effect of Volatility

\begin{tabular}{ccc}
\hline Variable & Estimates & t-value \\
\hline Intercept & 1.31 & $12.72^{* * *}$ \\
Day (-2) & 0.04 & 0.26 \\
Day (-1) & -0.05 & -0.33 \\
Day 1 & 0.07 & 0.51 \\
Day 2 & -0.24 & $-1.66^{*}$ \\
Day 3 & 0.07 & 0.45 \\
\hline
\end{tabular}

${ }^{*},{ }^{* *}$, and ${ }^{* * *}$ indicate significance at $10 \%, 5 \%$, and $1 \%$, respectively.

\section{Conclusions}

This paper examines how the cross-sectional volatility of the Jordanian stock market may change due to the day of the week, turn of the month and turn of the year. Results show strong evidence of reduction of volatility on Thursday compared to Sunday. Also the first three days of the month have significantly lower volatility compared to the third day before the last day of the month. Thus results indicate that a moderately risk averse investor should not trade on Sunday or at the end of the month. Seasonality in volatility does not guarantee any kind of abnormal returns. However, it can help 
a trader to act more safely by reducing the chance of loss. This finding is important to a risk-averse investor since he/she believes that the pain of losing a dollar is more than the enjoyment of winning a dollar.

Another important finding is that the seasonality of volatility vanished during the period $12 / 2011-02 / 2015$. This may be related to the economic condition of Jordan. Lack of interest and enthusiasm may play a role in the reduction of divergence of beliefs and volatility. During the same period the Jordan stock market has also been on a downward trend in terms of important performance indicators such as $\mathrm{P} / \mathrm{E}$ ratio, market capitalization, volume of trade, turnover ratio and index value. The reason could be the decrease in oil price in other notable oil-dependent countries in the Arab world those happen to be important trade partners, high regional political uncertainty and overall world-wide economic slowdown in the aftermath of the financial crisis of the USA in 2008. Thus, it is difficult to conclude whether or not the Jordan stock market can be blamed for its lackluster performance in past few years.

\section{Appendix}

\section{A. Industries in the Amman Stock Exchange}

\begin{tabular}{|c|c|c|}
\hline Industries and Sectors & $\begin{array}{l}\text { Number of } \\
\text { Firms }\end{array}$ & Total \\
\hline \multicolumn{3}{|l|}{ Financial } \\
\hline Banks & 15 & \\
\hline Insurance & 24 & \\
\hline Diversified Financial Services & 37 & \\
\hline Real Estate & 34 & \\
\hline \multicolumn{3}{|l|}{ Total } \\
\hline \multicolumn{3}{|l|}{ Services } \\
\hline Health care Services & 4 & \multirow{2}{*}{110} \\
\hline Educational Services & 6 & \\
\hline \multirow{4}{*}{$\begin{array}{c}\text { Hotels and Tourism } \\
\text { Transportation } \\
\text { Technology and Communication } \\
\text { Media }\end{array}$} & 11 & \multirow[b]{7}{*}{54} \\
\hline & 12 & \\
\hline & & \\
\hline & $\begin{array}{l}2 \\
2\end{array}$ & \\
\hline Utilities and Energy & $\begin{array}{l}2 \\
4\end{array}$ & \\
\hline Commercial Services & $\begin{array}{c}4 \\
13\end{array}$ & \\
\hline Total & & \\
\hline \multirow{2}{*}{$\begin{array}{c}\text { Pharmaceutical and Medical } \\
\text { Industries }\end{array}$} & & \\
\hline & 6 & \\
\hline Chemical Industries & 9 & \\
\hline Paper and Cardboard Industries & 3 & \\
\hline Printing and Packaging & 1 & \\
\hline Food and Beverages & 11 & \\
\hline Tobacco and Cigarettes & $\begin{array}{c}2 \\
16\end{array}$ & \\
\hline Mining and Extraction Industries & $\begin{array}{c}16 \\
7\end{array}$ & \\
\hline Engineering and Construction & 1 & \\
\hline Electrical Industries & $\begin{array}{l}4 \\
6\end{array}$ & \\
\hline Textiles, Leathers and Clothings & $\begin{array}{l}0 \\
1\end{array}$ & \\
\hline Glass and Ceramic Industries & & 67 \\
\hline $\begin{array}{c}\text { Total } \\
\text { Total of all listed Companies }\end{array}$ & & 231 \\
\hline
\end{tabular}

\section{REFERENCES}

[1] Abdul-Khaliq, S. (2013). "The Impact of Stock Market Liquidity on Economic Growth in Jordan", European Journal of Business and Management, Vol. 5, No. 30, 154-158.

[2] Abu Hashish, K. (2003). "The Role of Published Accounting Information in Predicting of Stock Prices", An Applied Study on Listed Corporations on Amman Stock Exchange, Al Basa'er Magazine/ Petra University, Amman, Issue 2.

[3] Abu Shanab, S. A. (2008). "The Impact of Returns and Risks on Share Prices: An Applied Study on Industrial Corporations Listed at Amman Stock Exchange", Unpublished Doctorate Thesis, Amman Arab University for Higher Studies, Amman, Jordan.

[4] Al-Ammarneh,A. et al. (2011)."Institutional Preferences: Evidence from the Jordanian Stock market", International Journal of economics and Finance, Vol. 3, No. 5, 97-103.

[5] Al-Jarrah, et al. (2011). "The Turn of the Month Anomaly in Amman Stock Exchange: Evidence and Implications", Journal of Money, Investment and Banking, Vol. 21, No. 2, $5-11$.

[6] Alrabadi, D. W. H. and Al-Qudah, K. A. (2012). "Calendar Anomalies: The Case of Amman Stock Exchange", International Journal of Business and Management, Vol. 7, No. 24, 120-127.

[7] AL Kurdi, A. (2005). "The Ability Range of Published Accounting Information on Stock Prices Prediction: An Applied Study on Public Shareholding Corporations on Amman Security Exchange", Unpublished Doctorate Thesis, Arab Academy for Financial and Banking Sciences, Amman, Jordan.

[8] AL Qudah, Y., M. (2004). "The Role of Accounting Revelation in Showing the Real Market Value of Exchanged Corporations' Stocks in Amman Security Exchange", Unpublished Doctorate Thesis, Arab Academy for Financial and Banking Sciences, Amman, Jordan.

[9] Al-rjoub, S. A. M. (2004). "The Daily Return Pattern in the Amman Stock Exchange and the Weekend Effect", SSRN Electronic Journal.

[10] Camilleri, S. J. (2008). "Month-related Seasonality of Stock Price Volatility: Evidence from the Malta Stock Exchange", Bank of Valletta Review, Vol. 37, No.1, 49-65.

[11] DeBondt, W. F. and R. H. Thaler (1985). "Does the Stock Market Overreact?” Journal of Finance, Vol. 40, No. 3, 793-805.

[12] DeBondt, W. F. and R. H. Thaler (1987). "Further Evidence on Investor Overreaction and Stock Market Seasonality", Journal of Finance, Vol. 42, No. 3, 567-580.

[13] El-Erian, M. and M. Kummar (1995). "Emerging Equity Markets in Middle Eastern Countries", IMF Staff Paper, Vol. 42, No. 2, 313-343.

[14] Fama, E. F. (1965). “The Behavior of Stock Market Prices”, Journal of Business, Vol. 38, No. 1, 34 - 105.

[15] Fama, E. F. (1970). "Efficient Capital Markets: A Review of Theory and Empirical Work", Journal of Finance, Vol. 25, No. $2,383-417$.

[16] Gompers, P. and Metrick, A. (1998). "Institutional Investors and Equity Prices", NBER Working paper No.6723. 
[17] Harvey, C. R. (1995). "The Cross-section of Volatility and Autocorrelation in Emerging Markets", Finanzmarkt und Portfolio Management, Vol. 9, No. 3, 12-29.

[18] Kabajeh, M. A. et al. (2012). "The Relationship between the ROA, ROE and Ratios with Jordanian Insurance Public Companies Market Share Price", International Journal of Humanities and Social Science, Vol.2, No. 11, 115-120.

[19] Kharwish, H. et al. (2010). "The Relationships between Stock Market Capitalization Rate and Interest Rate: Evidence from Jordan", Business and Economic Horizons, Vol.2, No. 2, 60-61.

[20] Maghayereh, A. (2003). "Casual Relations among Stock Prices and Macroeconomic Variables in the Small, Open Economy of Jordan", Journal of King Abdul-Aziz University: Economic \& Administration, Vo. 17, No.2, 3-12.

[21] Maghayereh, A. (2004). "Seasonality and January Effect Anomalies in the Jordanian Capital Market", The Arab Bank Review, Vo.15, No. 2, 1-17.

[22] Mawla, E. (2011). "Indicators to Measure Stock market Liquidity and Its Impact on Economic Growth", Tikrit Journal for Administrative \& Economic sciences, Vol. 7, 154-158.

[23] Nassir, A. and Mohammad, S. (1987), "The January Effect of Stocks Traded on the Kuala Lumpur Stock Exchange: An Empirical Analysis", Hong Kong Journal of Business management, Vol. 5, No. 5, 33-50.

[24] Polak, P. and Ejaz, A. (2004). "Short-term Momentum Effect: A Case of Middle East Stock Markets", Business: Theory and Practice, Vol. 16, No.1, 104-112.

[25] Rakotomavo, Michel (2009). "Microstructure and Institutional Holdings", Journal of Money, Investment and banking, Vol. 2, No. 7, 1-19.

[26] Rozeff, M. and Kinney, W. (1976). "Capital Market Seasonality: The Case of Stock Return", Journal of Financial Economics Vol. 3, No. 4, 379-402.

[27] Rubin, A. and Smith, D. (2009). "Institutional Ownership, Volatility and Dividends", Journal of Banking Finance, Vol. 33, No.4, 627-639.

[28] Sedik, T. and Petri, M. (2006). "The Jordanian Stock Market - Should You Invest in It for Risk Diversification or Performance?" International Monetary Fund, WP/06/187. 